\title{
Heat treating of the antifriction deposited layers by thermal spraying
}

\author{
A. V. Petrica ${ }^{1} \&$ L. Milos ${ }^{2}$ \\ 1 "Eftimie Murgu" University, Resita, Romania \\ 2 "Politehnica" University, Timisoara, Romania
}

\begin{abstract}
The first section of the paper presents the thermal spraying technology of the deposited layers. The X-ray diffraction analysis and the electron-scan microscopic analysis of these layers leads to the conclusion that the obtained microstructure does not reduce the anti-friction quality of these layers. The temperature of these layers during processing is relatively lower in relation with the temperatures used in the heat treatments. The second part of this paper presents the results obtained after a heat treatment of these layers. The same analysis after the heat treatment shows the appearance of some compounds that significantly improve the anti-friction property of these layers.
\end{abstract}

Keywords: thermal spraying, anti-friction layers, X-ray diffraction, electronscan microscopically analysis, heat treatment.

\section{Introduction}

From the microstructural point of view the thermally sprayed layers must have some stability to the temperatures that were reached during the exploitation, for preserving the functional characteristics. Thus, the heat treatment of these layers before the exploitation could confer a higher stability. Also, a heat treatment that changes the initial microstructure of the sprayed layers could lead to improve the exploitation performances of these layers. The basic quality of the Babbitt casting alloys is the anti-friction property, obtained grace to the presence of the $\mathrm{SnSb}$ and $\mathrm{Cu}_{3} \mathrm{Sn}$ crystals in the eutectic. The thermal spraying procedures can be a solution for the partial or total replacement of the boundary layer to some pieces. The Babbitt layer deposited by thermal spraying must keep the same 
functional characteristics in relation with the previous layer. So, the microscopic and the X-ray diffraction analysis can prove this aspect in a good manner.

\section{Experimental samples}

The appendix material used, its chemical composition and the parameters of the procedure recommended by the manufacturer of the wire are inserted in tables 1 and 2. The dimensions of the samples for the microscopic and the X-ray diffraction analysis were $20 / 25 \mathrm{~mm}$ (fig. 1). The final thickness of the layer was obtained after four passes and it is of $3 \mathrm{~mm}$.

Table 1: The chemical composition of the appendix material used to thermal spraying by flame and wire.

\begin{tabular}{|c|c|c|c|c|c|}
\hline \multirow{2}{*}{ Type of wire } & \multicolumn{4}{|c|}{ Chemical composition, [\%] } & \multirow{2}{*}{ Wire diameter, [mm] } \\
\cline { 2 - 5 } & $\mathrm{Sn}$ & $\mathrm{Sb}$ & $\mathrm{Cu}$ & $\mathrm{Pb}$ & \\
\hline Sprababbitt A & 87,75 & 7,5 & 3,5 & 0,25 & 3,2 \\
\hline
\end{tabular}

Table 2: $\quad$ The parameters used in thermal spraying with flame and wire procedure.

\begin{tabular}{|c|c|c|c|c|c|c|}
\hline $\begin{array}{c}\text { Rotation, } \\
{[\mathrm{rot} / \mathrm{min}]}\end{array}$ & $\begin{array}{c}\text { Spraying } \\
\text { distance, }[\mathrm{mm}]\end{array}$ & $\begin{array}{c}\text { Oxygen and } \\
\text { acetylene } \\
\text { pressure, }[\mathrm{bar}]\end{array}$ & $\begin{array}{c}\text { Wire } \\
\text { speed, } \\
{[\mathrm{cm} / \mathrm{s}]}\end{array}$ & $\begin{array}{c}\text { Compressed air } \\
\text { pressure, }[\mathrm{bar}]\end{array}$ & $\begin{array}{c}\text { Angle of } \\
\text { spraying, } \\
{\left[{ }^{\circ}\right]}\end{array}$ & $\begin{array}{c}\text { Layer } \\
\text { temp., } \\
{\left[{ }^{\circ} \mathrm{C}\right]}\end{array}$ \\
\hline 200 & $100-120$ & 2 & 2 & 3,65 & max. 45 & $80-100$ \\
\hline
\end{tabular}

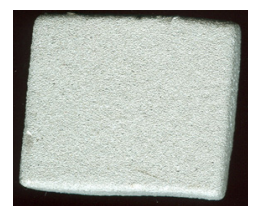

Figure 1: Macroscopic image of the sample, deposited layer - Babbitt.

\section{The X-ray diffraction analysis}

The purpose of this analysis was to find the nature of the microstructural constituents for the used appendix material. Also we followed the evolution of possible structural changes in the case of some heat treatments performed on the deposited layers.

The experiments were made off with the DRON 3 X-ray difractometer using the characteristic radiation $\mathrm{K} \alpha$ of molybdenum $(\lambda=0,71 \AA)$. The parameters of the equipment were: $U_{\text {acc }}=40 \mathrm{KV}$ and $\mathrm{I}=30 \mathrm{~mA}$. The speed of the detector was $2 \% \mathrm{~min}$ for the recordings made off in $2 \theta=7 \ldots 55^{\circ}$ angular domain, and $(1 / 2)^{\circ} / \mathrm{min}$ for the recordings made off in $2 \theta=30 \ldots 41^{\circ}$ angular domain.

The diffraction spectrums obtained by these analysis are presented in figures 2 and 3 . The values for these analyses are inserted in tables 3 and 4 . 
Table 3: $\quad$ The values for the non-heat treated sample.

\begin{tabular}{|c|c|c|c|c|}
\hline Pick no. & Angle $2 \theta$ & $\mathrm{d}[\AA]$ & $(\mathrm{h} 1)$ & Phase \\
\hline 1 & 13,95 & 2,92 & $(200)$ & $\mathrm{Sn}(\mathrm{Sb}, \mathrm{Cu})$ \\
\hline 2 & 14,50 & 2,81 & $(101)$ & $\mathrm{Sn}(\mathrm{Sb}, \mathrm{Cu})$ \\
\hline 3 & 19,65 & 2,08 & $(220)$ & $\mathrm{Sn}(\mathrm{Sb}, \mathrm{Cu})$ \\
\hline 4 & 20,35 & 2,01 & $(211)$ & $\mathrm{Sn}(\mathrm{Sb}, \mathrm{Cu})$ \\
\hline 5 & 24,85 & 1,65 & $(301)$ & $\mathrm{Sn}(\mathrm{Sb}, \mathrm{Cu})$ \\
\hline 6 & 27,75 & 1,48 & $(112)$ & $\mathrm{Sn}(\mathrm{Sb}, \mathrm{Cu})$ \\
\hline 7 & 28,20 & 1,45 & $(400)$ & $\mathrm{Sn}(\mathrm{Sb}, \mathrm{Cu})$ \\
\hline 8 & 28,45 & 1,44 & $(133)$ & $\mathrm{Sb}_{2} \mathrm{O}_{4}$ \\
\hline 9 & 31,55 & 1,30 & $(035)$ & $\mathrm{Sb}_{2} \mathrm{O}_{4}$ \\
\hline 10 & 31,85 & 1,293 & $(420)$ & $\mathrm{Sn}(\mathrm{Sb}, \mathrm{Cu})$ \\
\hline 11 & 34,25 & 1,205 & $(312)$ & $\mathrm{Sn}(\mathrm{Sb}, \mathrm{Cu})$ \\
\hline 12 & 37,75 & 1,097 & $(431)$ & $\mathrm{Sn}(\mathrm{Sb}, \mathrm{Cu})$ \\
\hline 13 & 39,85 & 1,041 & $(332)$ & $\mathrm{Sn}(\mathrm{Sb}, \mathrm{Cu})$ \\
\hline 14 & 40,45 & 1,026 & $(440)$ & $\mathrm{Sn}(\mathrm{Sb}, \mathrm{Cu})$ \\
\hline 15 & 42,35 & 0,982 & $(441)$ & $\mathrm{Sn}(\mathrm{Sb}, \mathrm{Cu})$ \\
\hline 16 & 44,90 & 0,929 & $(512)$ & $\mathrm{Sn}(\mathrm{Sb}, \mathrm{Cu})$ \\
\hline 17 & 47,20 & 0,886 & $(323)$ & $\mathrm{Sn}(\mathrm{Sb}, \mathrm{Cu})$ \\
\hline 18 & 49,50 & 0,848 & $(413)$ & $\mathrm{Sn}(\mathrm{Sb}, \mathrm{Cu})$ \\
\hline
\end{tabular}

Table 4: $\quad$ The values for the heat treated sample.

\begin{tabular}{|c|c|c|c|c|}
\hline Pick no. & Angle $2 \theta$ & $\mathrm{d}[\AA]$ & (hkl) & Phase \\
\hline 1 & 13,25 & 3,077 & $(200)$ & $\mathrm{SnSb}$ \\
\hline 2 & 14,00 & 2,91 & $(200)$ & $\mathrm{Sn}(\mathrm{Sb}, \mathrm{Cu})$ \\
\hline 3 & 14,55 & 2,803 & $(101)$ & $\mathrm{Sn}(\mathrm{Sb}, \mathrm{Cu})$ \\
\hline 4 & 18,90 & 2,162 & $(220)$ & $\mathrm{SnSb}$ and $\varepsilon-\mathrm{Cu}_{3} \mathrm{Sn}(002)$ \\
\hline 5 & 19,70 & 2,075 & $(220)$ & $\mathrm{Sn}(\mathrm{Sb}, \mathrm{Cu})$ and $\varepsilon-\mathrm{Cu}_{3} \mathrm{Sn}(2.12 .0)$ \\
\hline 6 & 20,40 & 2,005 & (211) & $\mathrm{Sn}(\mathrm{Sb}, \mathrm{Cu})$ \\
\hline 7 & 23,20 & 1,765 & $(222)$ & $\mathrm{SnSb}$ \\
\hline 8 & 24,05 & 1,704 & $(310)$ & $\mathrm{Sb}_{2} \mathrm{O}_{4}$ \\
\hline 9 & 24,80 & 1,653 & $(301)$ & $\mathrm{Sn}(\mathrm{Sb}, \mathrm{Cu})$ \\
\hline 10 & 26,85 & 1,529 & $(400)$ & $\mathrm{SnSb}$ \\
\hline 11 & 27,75 & 1,480 & (112) & $\mathrm{Sn}(\mathrm{Sb}, \mathrm{Cu})$ \\
\hline 12 & 28,20 & 1,457 & $(400)$ & $\mathrm{Sn}(\mathrm{Sb}, \mathrm{Cu})$ \\
\hline 13 & 28,50 & 1,442 & (133) & $\mathrm{Sb}_{2} \mathrm{O}_{4}$ \\
\hline 14 & 30,12 & 1,366 & $(420)$ & $\mathrm{SnSb}$ and $\varepsilon-\mathrm{Cu}_{3} \mathrm{Sn}(083)$ \\
\hline 15 & 31,50 & 1,307 & $(035)$ & $\mathrm{Sb}_{2} \mathrm{O}_{4}$ \\
\hline 16 & 31,90 & 1,292 & $(420)$ & $\mathrm{Sn}(\mathrm{Sb}, \mathrm{Cu})$ \\
\hline 17 & 33,20 & 1,242 & $(422)$ & $\mathrm{SnSb}$ and $\varepsilon-\mathrm{Cu}_{3} \mathrm{Sn}(2.26 .1)$ \\
\hline 18 & 34,40 & 1,200 & $(312)$ & $\mathrm{Sn}(\mathrm{Sb}, \mathrm{Cu})$ \\
\hline 19 & 37,90 & 1,0293 & $(431)$ & $\mathrm{Sn}(\mathrm{Sb}, \mathrm{Cu})$ \\
\hline 20 & 39,95 & 1,039 & $(332)$ & $\mathrm{Sn}(\mathrm{Sb}, \mathrm{Cu})$ and $\varepsilon-\mathrm{Cu}_{3} \mathrm{Sn}(174)$ \\
\hline 21 & 40,70 & 1,021 & $(440)$ & $\mathrm{Sn}(\mathrm{Sb}, \mathrm{Cu})$ \\
\hline 22 & 42,45 & 0,980 & (441) & $\mathrm{Sn}(\mathrm{Sb}, \mathrm{Cu})$ \\
\hline 23 & 43,12 & 0,966 & $(620)$ & $\mathrm{SnSb}$ \\
\hline 24 & 45,00 & 0,927 & $(512)$ & $\mathrm{Sn}(\mathrm{Sb}, \mathrm{Cu})$ \\
\hline 25 & 45,40 & 0,920 & $(622)$ & $\mathrm{SnSb}$ and $\varepsilon-\mathrm{Cu}_{3} \mathrm{Sn}(5.21 .1)$ \\
\hline 26 & 47,20 & 0,887 & (323) & $\mathrm{Sn}(\mathrm{Sb}, \mathrm{Cu})$ \\
\hline 27 & 49,55 & 0,847 & (413) & $\mathrm{Sn}(\mathrm{Sb}, \mathrm{Cu})$ and $\varepsilon-\mathrm{Cu}_{3} \mathrm{Sn}(0.8 .5)$ \\
\hline
\end{tabular}




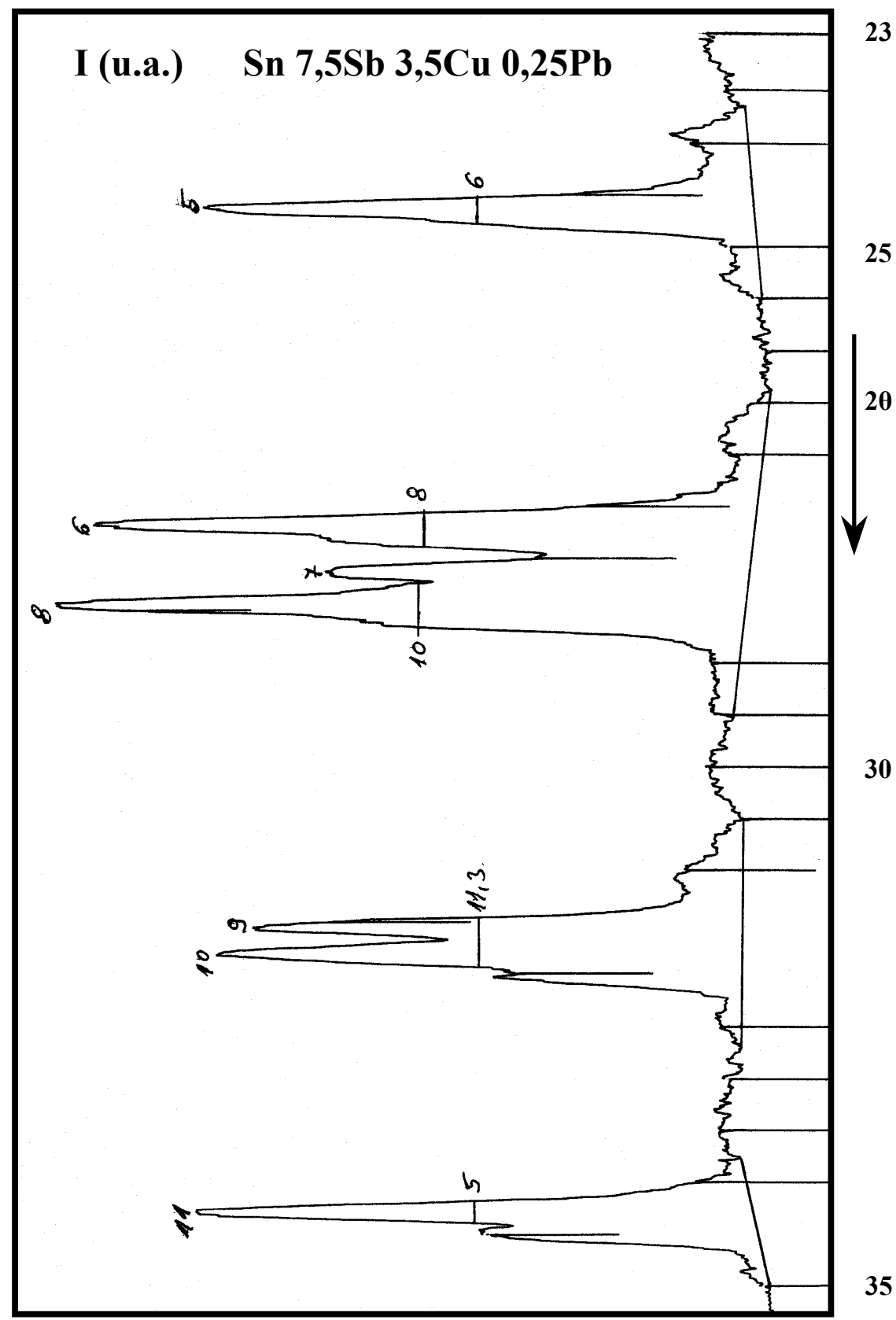

Figure 2: The partial spectrum of diffraction characteristic to the non-heat treated deposited layer. 


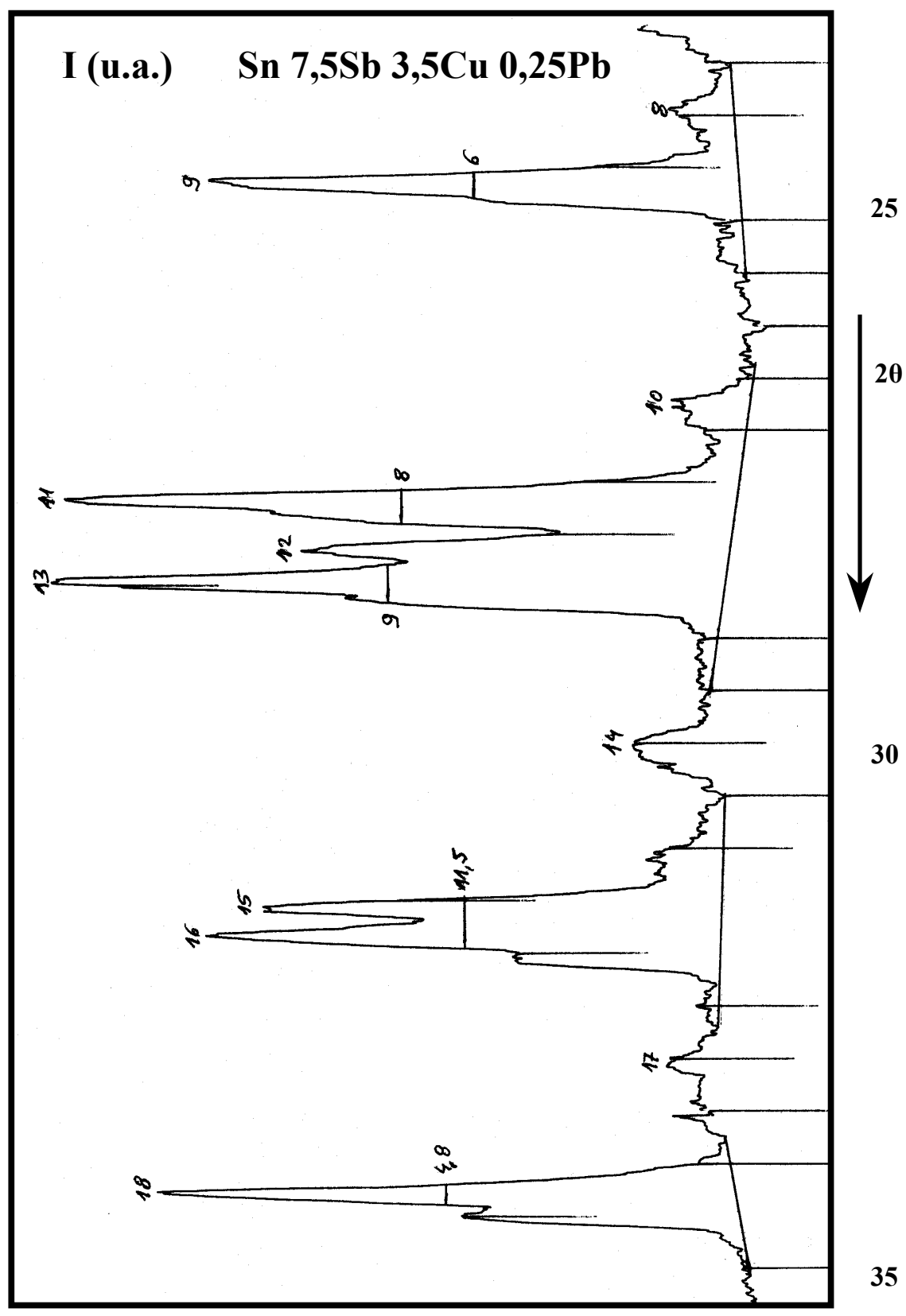

Figure 3: The partial spectrum of diffraction characteristic to the heat treated deposited layer. 
Two types of samples were analyzed. The first sample was non-heat treated, and the second sample was heat treated as follows: $150^{\circ} \mathrm{C}$ heating temperature, one- hour time keeping, cooling in the furnace.
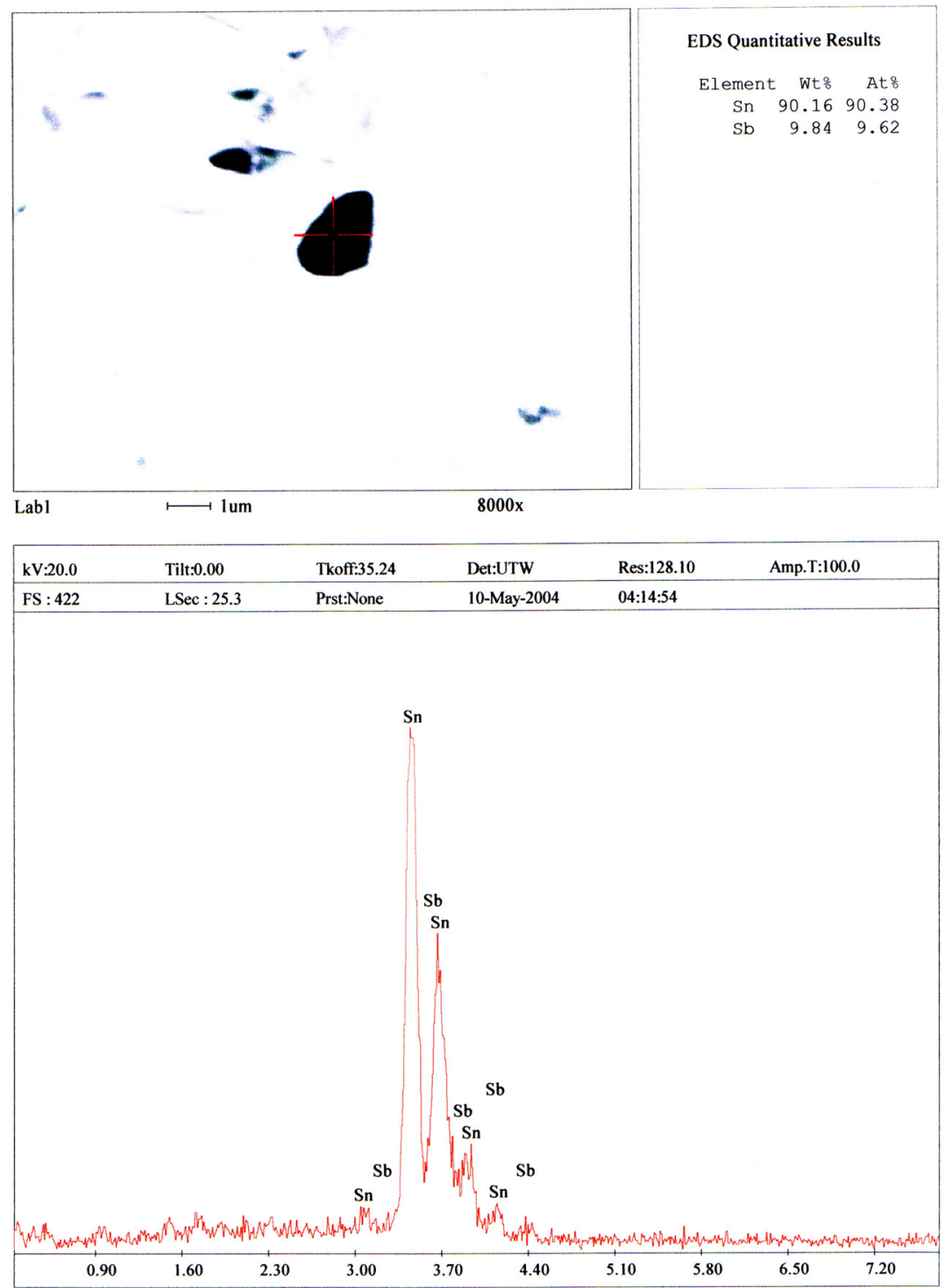

Figure 4: The quantitative chemical analysis to the deposited layer $-\mathrm{SnSb}$ compound. 
The following aspects are pointed out:

$\checkmark \quad$ The occurrence of the $\mathrm{Sb}$ and $\mathrm{Cu}$ solid solution in $\mathrm{Sn}$;

$\checkmark \quad$ The occurrence of the Sb oxide (pick no. 8 and 9) - to the non-heat treated sample;

$\checkmark$ The absence of the $\mathrm{SnSb}$ crystals and $\mathrm{Cu}_{3} \mathrm{Sn}$ needles - to the non-heat treated sample;

$\checkmark$ After the heat treatment the structure of the deposited layer is significantly modified by the occurrence of the $\mathrm{SnSb}$ and $\mathrm{Cu}_{3} \mathrm{Sn}$ compounds.

\section{The microscopic analysis}

This analysis became necessary after the X-ray diffraction analysis, which pointed out the occurrence of the $\mathrm{SnSb}$ and $\mathrm{Cu}_{3} \mathrm{Sn}$ compounds after a heat treatment.

In the $4^{\text {th }}$ figure we presented the chemical quantitative analysis of the compound from the image. One can remark only the presence of $\mathrm{Sn}$ and $\mathrm{Sb}$, the compound tends to have a regular shape like the $\mathrm{SnSb}$ compounds from the molten state. It is obvious that the colour of this compound is different from the colour of the basic metallic matrix, due to the BSE (back scattered - electron) analysis. The small quantity of this compound it's maybe the result of a short time keeping ( 1 hour) at the $150^{\circ} \mathrm{C}$ temperature.

\section{Conclusions}

- In the non-heat treated Babbitt layers the $\mathrm{SnSb}$ and $\mathrm{Cu}_{3} \mathrm{Sn}$ crystals are not present;

- The X-ray diffraction analysis of the heat treated Babbitt layers points out the occurrence of these compounds;

- The quantitative microscopic analysis attests the occurrence of the $\mathrm{SnSb}$ compound;

- The detection of the $\mathrm{Cu}_{3} \mathrm{Sn}$ compound is more difficult to achieve because of the shape of this compound (acicular, in the case of molten Babbitt) and because of its small dimension.

- The occurrence of these compounds in the structure of the Babbitt layers deposited by thermal spraying contributes to the improvement of the basic quality of these layers, namely the anti-friction property.

\section{Reference}

[1] Petrica A., Contributions to the increase of the availability of the boring type pieces, Doctor's degree thesis, September 2004, "Politehnica" University of Timisoara. 